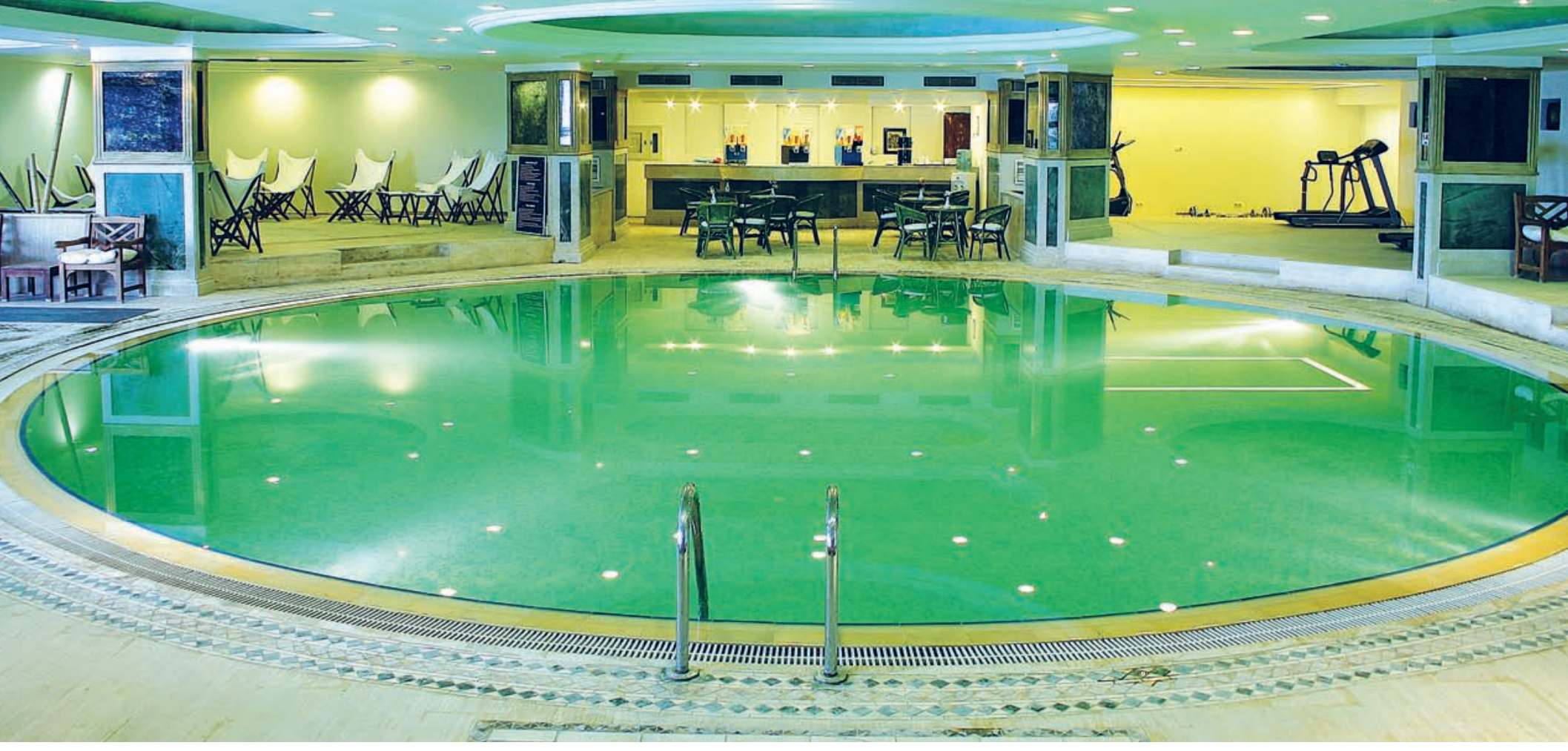

Dr. habil. Müller Anetta ${ }^{1}$ - Seres János ${ }^{1}$ - SzÉles-Kovács GyUla $^{1}$ - Kristonné Dr. Bakos MagdolnA ${ }^{1}$ - VÁczi PÉter ${ }^{1}$

${ }^{1}$ Eszterházy Károly Főiskola Testnevelés és Sporttudományi Intézet, Eger

\title{
A testnevelő tanárok munkaerőpiaci szerepe az egészségturizmus területén
}

Labour Market's Role of the Physical Education Teacher in the Health Tourism

10.21486/recreation.2011.1.1.3

BEVEZETÉS

Hajdanán elsősorban a testnevelő tanár látta el az iskolai testnevelés órák megtartását, ő volt az, aki a délutáni edzéseket levezette és részt vállalt a szabadidősport területén is. Ezért a testnevelő tanárképzés összetett volt, magába foglalta a fen- ti tevékenységekre történő felkészítést is. Ma azt tapasztaljuk, hogy a sportszakember-képzésben szakterületek szerinti differenciálódás következett be az iskolai testnevelés (testnevelő tanár képzés), a szabadidősport (rekreációs szakember képzés) és a versenysport (edző képzés) kompetenciáinak oktatásában. Amennyiben a tanügyi reformokat, a mai testnevelés órák számát, a tanulók egészségi és fizikai teljesítőképességét, a sport társadalmi megítélését vesszük figyelem- 


\section{ÖssZEFogLaLÁs}

A wellness szállodáknak a vonatkozó rendelet szerint (54/2003 GKM rendelet) az alábbi kínálati elemekkel kell rendelkezniük: fürdő, szauna, szépségápolással kapcsolatos szolgáltatások, terápiás és relaxációs kezelések, közösségi programok, sportprogramok (animációval) valamint reformtáplálkozási kínálat. A testnevelő tanárok részt tudnak vállalni a különféle sportprogramok megszervezésében és lebonyolításában. Ezért a testnevelők képzésében szerepeltetni kell az egészségturizmus, a rekreáció ismeretanyagát, melyben a programszervezés kompetenciájának kialakítása a cél. A rekreációs tevékenységek, a sportprogramok a turisztikai termékfejlesztés egyik alternatívái lehetnek az egészségturizmus területén.

Kulcsszavak: egészségturizmus, animátor, testnevelő tanár be, akkor nem lehetünk elégedettek a kialakult helyzettel, talán még mostohább a helyzet, mint valaha. A NAT bevezetésével ugyanis a testnevelés órák száma 47\%-kal csökkent (Istvánfy 1999.), mely ugyancsak a gyermekek életének mozgásszegényebbé válását eredményezte. Nem is olyan régen megkérdőjelezték a testnevelés osztályozásának létjogosultságát. Azok a szakemberek, akik testnevelő tanár BSc diplomát kapnak, nem kapnak jogosultságot a tanításra, azonban a munkaerőpiaci elvárásoknak megfelelve lehetőség nyílik az egészségturizmus területén a wellness szállodák sport, szabadidős és közösségi programjainak lebonyolításában, való feladatkör betöltésére.

\section{IRODALMI ÁTTEKINTÉS}

Mit értünk az egészség fogalma alatt? A Révai Nagy Lexikona (1991) szerint: „az egészség a betegségekkel ellentétes fogalom. Jelzi valamely élőlénynek azt az állapotát, melyben minden szerv teljes működési képességű.” - ezt a definíciót csupán a biológiai lények (növények, állatok) esetében fogadhatjuk el. Az ember „természeti” lényből „társadalmi” lénnyé fejlődött, így esetében a biológiai jellegű egészség értelmezés koránt sem tekinthető teljes értékủnek. $\mathrm{Az}$ ember szociális lény is, fontos a kiegyensúlyozott élethez a baráti-, családi-, munkahelyi kapcsolatok rendszere. Ezt példázza nekünk Kipling a „Dzsungel könyvében” Maugli történetével. A vadonban, a társadalomtól messze felnövekvő „vadóc” nem tekinthető a mindennapi értelemben vett emberi lénynek. Az embert a nyelv használata, a társakkal való kommunikáció, a társas kapcsolatok rendszere teszi igazán emberré. Ezen kívül- az ember pszichológiai lény is, vagyis fontos a lelki egészség megőrzése és fejlesztése a pszichikus ártalmak és betegségek megelőzése, melyet a mentálhigiéné (Buda, 1998) fogalmával fejezhetünk ki.

$\mathrm{Az}$ Egészségügyi Világszervezet (World Health Organization WHO) egészség definíciója már komplexen értelmezi az egészséget, nem csupán a betegségektől való mentességet jelenti, hanem: „teljes testi, lelki és szociális jólét” állapotaként. Cooper (1990) az egészséget „tökéletes közérzetnek” nevezi, arra hívja fel a figyelmet, hogy ez egy egyensúlyi állapot, amiért mindig a „megfelelőt” (sportmozgás, pihenés, alvás, evés, stb.) kell tennünk, se többet, se kevesebbet!

Abraham Maslow (1968) felhívja a figyelmet a mentális egészség kérdésére. Szerinte az alapvető pszichoszociális szükségletek kielégítése, másrészt bizonyos megterhelő körülmények kiküszöbölése egyaránt feltételei a mentális egészségnek.

A wellness értelmezések közül érdekes Dunn összetett koncepciója.

A wellness hat legfontosabb ismérve (Dunn H. Travis, 1985):

- Az egyén egészséghez kapcsolódó felelősségtudata

- Rendszeres testmozgás

- Egészséges táplálkozás (ételek és italok megválogatása)

- Káros szenvedélyek (élvezeti cikkek, függőséget okozó szerek) kerülése, óvatosság a gyógyszerek szedésében

- Rendszeres ellazulás és stresszkezelés
• Környezetbarát szemléletmód (környezettudatosság).

A wellness tehát olyan életforma, amely hozzásegíti az embereket ahhoz, hogy egészségesebbek, karcsúbbak, boldogabbak legyenek, vagy csak egész egyszerűen jól érezzék magunkat a bőrükben, mivel a többi egészségmegőrző programmal ellentétben a wellness az embert holisztikusan, azaz egységként szemléli. Fő ismérvei: a tudatos egészségmegőrzés, a rendszeres testmozgás, az egészséges táplálkozás, a káros szerek kerülése, a rendszeres ellazulás, a relaxáció, a stresszkezelés és a környezetbarát szemléletmód.

Az egészségturizmus összefoglaló néven tartalmaz minden, az egészséggel kapcsolatos utazási típust. Az egészségturizmusban a látogatók alapvető motivációja az egészségi állapot megőrzése, fejlesztése a deformitások és betegségek megelözése (wellness turizmus) valamint az egészségi állapot javítása, a kialakult betegségek gyógyítása (gyógyturizmus) illetve a képességek fejlesztése és a fizikai teljesítőképesség növelése (fitness turizmus). Azt mondhatjuk, hogy az egészség megőrzése, vagy helyreállítása érdekében tett utazások összességét tekintjük egészségturizmusnak (Müller-Könyves, 2006).

A betegségek gyógyítása igen komoly terhet ró a társadalomra. Az országos egészségbiztosítási pénztár (OEP), mint feneketlen kút nyeli el a befizetett összegeket és olykor még ez is kevésnek bizonyul. A betegségek gyógyítása helyett a prevenció költséghatékonyabbnak mondható, nem beszélve arról, hogy az egyénnek is kellemesebb. Ezért tapasztaljuk azt, hogy a gyógyturizmus - mely a megromlott egészségi

\section{Abstract}

According to the related government decree (54/2003 Ministry of Economics and Traffic MET decree) a wellness hotel shall provide the following services: pool, sauna, beauty-programs, therapy and relax services, social events and sports program (animation) and reform gastronomy. Physical education teachers can take part in the organization and management of sport programs. Hence we need to include the knowledge material of health tourism and recreation in the physical education teacher training program in which the aim is to build competence for program organization. Recreational activities or sport programs can be an alternative for touristic product development in the field of health tourism.

Keywords: health tourism, animation, PE teacher 
előzés bizonyítottan az élvezettel teli élet garanciája - az egészség egy életcél. A wellness célja: egy ésszerű, sikert ígérő és egészséges életstratégia követése.

A testnevelö tanárok, mint az egészségturizmus humáneröforrásai

A gyógyturizmus kínálati elemei a különböző terápiás eljárások, melyek orvosi hátteret igényelnek. Bár tudjuk, hogy a mozgás szerepel a terápiás módszerekben (gyógytorna), azonban erre a területre gyógytornász végzettség szükségeltetik.

Nézzük, meg mi van a másik, a wellness turizmus területével?

Németországban reprezentatív felmérés kereteiben (Der RDA Marktforschungsbericht, 2009, Reyseanalyse, 2009) megállapították, hogy a válság ellenére is 2007-ről 2008-ra egy mérsékelt bevétel növekedést értek el a hotelek, és az olcsóbb garniszállók, panziók. Míg 2007-ben 16,5 millió eurót addig 2008-ban 16,6 millió euró bevételt realizáltak (Der RDA Marktforschungsbericht 2009. 13.p.). Mérsékelt növekedés volt megfigyelhető a nyári nyaralások területén, míg 2007-ben a német lakosság 74,8\%-a, addig 2008-ban 76,2\%-a nyaralt. A több mint 5 napos nyaralások száma 2007-ben 62,9 millió volt, mely mérsékelten növekedett 2008-ra, hiszen 64 millióra nőtt. 2009-ben a német utazó lakosság 78\%-ának a legfóbb utazási motivációja a nyugalom, a pihenés, a meleg klíma, a változatosság (kiszakadni a mindennapokból) volt. A megkérdezettek harmadának a nyaralás során végzett fitnesz-aktivitás volt a tipikus szabadidős tevékenysége. A kutatás szerint az egészségorientált körutazások, városlátogatások, wellness utazások és kúraajánlatok népszerüsége nőtt 2009-ben, mely növekedése tovább prognosztizálható. 2009-ben ugyancsak nőtt a német szenior korosztály és fiatalok külföldi desztináció-választásai, melyet az egészségük megőrzése és fittségük magtartása valamint a hosszabb életkor reményében tettek (Der RDA Marktforschungsbericht 2009. 3.p.).

Mindebből prognosztizálható, hogy a demográfiai változások és az ezzel járó öregedő társadalom hatásaként az egészségturizmus a jövő turizmus piacának megatrendjévé válik.

Hazánkban is az egészségturizmus egyre népszerűbbé válik és növekvő keresletet tapasztalhatunk a termék iránt.

Kerényi és mtsai (2009) 2009 nyarán a Komáromi Gyógyfürdőben, az Agárdi Termál- és Gyógyfürdőben, és a Pápai Várkertfürdőben 375 fős mintán végzett fürdőkutatás során megállapították, hogy a fürdőválasztás motivációjában a pihenés és a rekreáció nagyobb szerepet játszott, mint maga a fürdő hírneve, hiszen ezek a fürdők még kevésbé bevezettettek az egészségturisztikai piacon, így ezek arculatát erősíteni szükséges.

Saját kutatásunk (Müller és mtsai, 2009) is igazolta, hogy a fürdőlátogatók körében egyre markánsabban fogalmazódik meg az igény a fürdőben lévő különböző sportos és wellness programok iránt.

A fürdők a testi-lelki és szociális jó közérzet, az egészség megőrzésének helyszíneivé válta, hiszen hazai kutatások igazolták a fürdőlátogatás beépült a mindennapok programjába. A rendszeres fürdőlátogatók igénylik a megszokott szabadidős és wellness szolgáltatásokat és azok minőségét., és ezt a turisztikai desztinációk fürdőinek termékfejlesztésük során érvényesíteni kell. (Müller-Kórik, 2009, Mosonyi és mtsai, 2010).

A Központi Statisztikai Hivatal adatai szerint 2009 decemberében a kereskedelmi szálláshelyet igénybe vevő külföldi vendégek száma 1,2\%-kal, az általuk eltöltött vendégéjszakák száma 3,5\%kal csökkent az előző év azonos időszakához viszonyítva. A belföldi vendégforgalomban a vendégek száma 9,4\%-kal, a vendégéjszakák száma 10,0\%-kal csökkent. Összességében a vendégek száma 5,9\%-kal, a vendégéjszakák száma 7,0\%kal maradt el az egy évvel azelőtti adatokhoz képest. Mind a külföldi mind a belföldi vendégforgalom csökkenésében érezhető a gazdasági válság hatása. (KSH, www.itthon.hu).

A gazdasági válság legnagyobb vesztesei a háromcsillagos szállodák voltak. 2008-ról2009re a 3 csillagos szállodák forgalma 14,8\%-kal csökkent, az 5 csillagos szállodáké 2,3\%-kal a négycsillagosoké $0,7 \%-k a l$ csökkent. A wellness szállodák forgalma csupán 0,3\%-kal. (KSH, www.itthon.hu). A válság kevésbé csökkentette a wellness keresleté, mely az előző években dinamikus forgalombővülést mutatott.

Magyarországon jelenleg a wellness szállodák kritériumrendszerét a kereskedelmi szálláshelyek osztályba sorolásáról szóló, többször módosított IKIM rendelet - a legújabb módosítása az 54/2003 (VIII.29) sz. GKM rendelet 2003. nov. 27-tól lépett életbe - szabályoz. A rendelet szerint a wellness szállodáknak az alábbi szolgáltatásokat kell kínálni:

1. „A szálloda minimum 1 féle beltéri fürdőmedencével rendelkezik(uszoda, pezsgőfürdő, élményfürdő, gyermekmedence).

2. A szálloda rendelkezik minimum 2 féle szauna vagy gőzfürdő létesítménnyel (finn szauna, bioszauna, infraszauna, gőzfürdő, aromakabin, törökfürdő, stb.).

3. A szálloda az arc-, test-, kéz-, láb- és hajápolási szolgáltatások közül legalább 4 féle szépségápolási lehetőséget nyújt (masszázsok, arckezelés, testtekercselés, ultrahangos testkezelés, hajápolás, fodrászat, pedikűr, stb.).

4. A szálloda legalább 6 féle masszázs, relaxációs és egyéb közérzetjavító - vizes és száraz szolgáltatást kínál (akupunktúra, akupresszúra, izzasztó pakolás, kiropraktika, Bach-terápia, kneipp kúra, léböjt, életmód-táplálkozási tanácsadás, sóbarlang, masszázstechnikák, stb.).

5. A szálloda gasztronómiai kínálatában szerepelnek a régióra jellemző, hagyományőrző magyar, továbbá reform- és vegetáriánus étel- és italajánlatok (gyógyteák, frissen préselt gyümölcslé, biobor).

6. A szálloda minimum 4 féle szabadidős sportolási vagy keleti mozgásprogramot kínál, és további minimum 1 féle aerobic jellegủ tréninget. (Kardio- és izomerősítő gépek
Dr. habil. Müller Anetta Ph.D. föisholai tanár

Eszterházy Károly Föishola

Testnevelési és Sporttudományi Intézet, Eger

e-mail:muller@ektf.hu

Fô hutatási témái az egészségturizmus és a szabadidögazdaság.

Hobbija a sportolás és az üvegfestés.

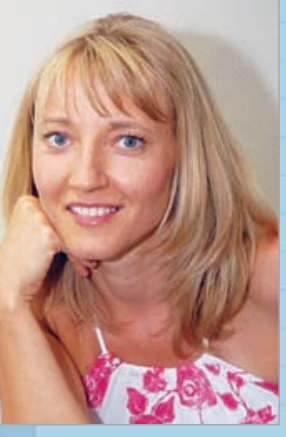




\section{MóDSZEREK}

\section{A vizsgálat célja:}

Kíváncsi voltam, hogy a leendő sportszakemberek milyen ismeretekkel rendelkeznek az animációról, valamint hogyan viszonyulnak az animátori munkakörhöz, mely jelentősen javíthatná a munkaerőpiacra jutásukat.

\section{A vizsgálat módszere:}

Az Eszterházy Károly Főiskola testnevelő tanári illetve az új képzési rendszer szerint testnevelö-edző BSc szakos hallgatói körében kérdöíves kutatási módszert alkalmaztam a vizsgálatomnál. Az adatokat SPSS 16.0-ás szoftver segítségével dolgoztam fel. A kérdőív válaszainak grafikus megjelenítéséhez, a diagramok készítéséhez Microsoft Office 2003 és 2007 Excel és Word programjait használtam.

\section{A minta:}

Az Eszterházy Károly Főiskola testnevelés szakos hallgatói töltötték ki a kérdöívemet. 76 kérdőívet dolgoztam fel, ezért felmérésem egy mintaként szolgál. Minden évfolyam képviselte magát a megkérdezettek között. A 76 megkérdezett nemek szerinti eloszlása, 37 nő és 39 férfi. 16 fő első évfolyamos, 7 fő másodévfolyamos, 17 fő harmadévfolyamos és 36 fő negyedévfolyamos hallgató adott választ.

A mintában az utolsó évfolyamosak képviseltették magukat dominánsan, ami azért jó, mert ők már többet foglalkoznak a munkaerőpiacra jutásukkal, munkaerő piaci értékeikkel és elhelyezkedési esélyeikkel.

\section{EREDMÉNYEK:}

Az animáció, az animátor fogalmának vizsgálata a testnevelés szakos hallgatók körében:

A fejezet kérdései:

- Tudod-e, mit jelent az animáció kifejezés, mivel foglalkozik a sportanimátor?

- Ismersz-e olyan személyt, aki dolgozott ilyen munkakörben?

- Szívesen elhelyezkednél-e ilyen munkakörben?

- Tanárként, vagy animátorként helyezkednél-e el szívesebben?

$\mathrm{Az}$ első kérdésem természetesen arra irányult, hogy tisztában vannak-e az animáció fogalmával. 64, 5 \%-uk (49 fö) tisztában van azzal, hogy mit jelent animáció, illetve mivel foglalkozik az animátor. A válaszadók 35,5 \%-a (27 fö) nem tudta, hogy mit takar ez a szolgáltatás, illetve munkakör.

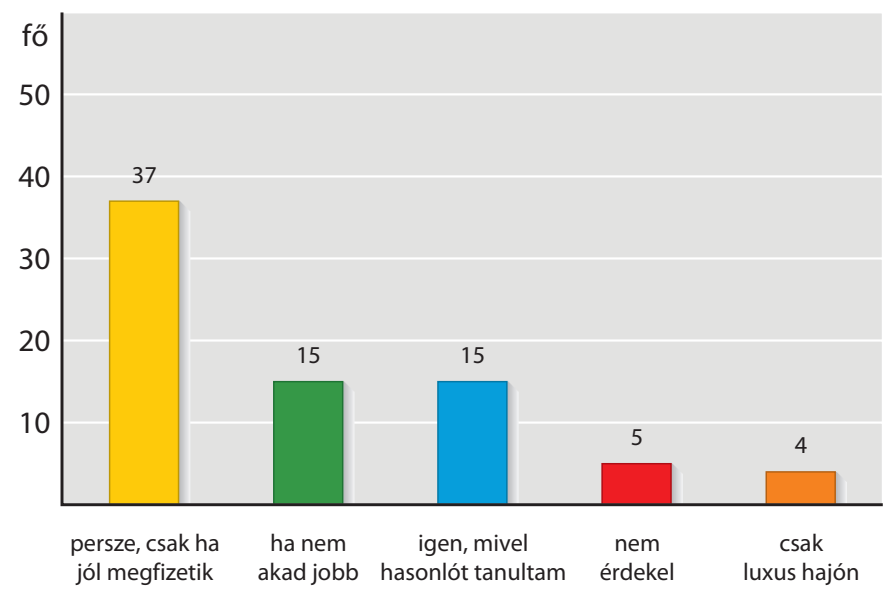

hasonlót tanultak (testnevelés szak). A válaszadók többsé gét - 37 válaszadót - a jó fizetés motiválná ennek a munkakörnek a betöltésére.

Ezt a kérdést másképp tettem fel a következőkben, még pedig, hogy animátor, vagy tanár lenne szívesebben, és ezek mellett választhatták azt is, hogy bármelyik, vagy egyikként sem (2. ábra).

Ezután a kérdés után röviden definiáltam az animációt és, hogy mit is csinál az animátor, és hol található ilyen szolgáltatás, illetve hol tölthetö be ez a munkakör. Ennek az volt a célja, hogy, aki nem ismeri, egy új lehetőségre hívjam fel a figyelmét, olyan munkakörre, amit betölthet. A másik célja az volt, hogy a következő kérdésekre tudjon így válaszolni az is, aki eddig nem ismerte ezeket a fogalmakat.

A következő kérdés az volt, hogy ismernek-e olyan személyt, aki animátorként dolgozott, dolgozik. Természetesen, aki nem tudta az elöző kérdésben, hogy mit takarnak ezek a fogalmak, azok „nem”-mel válaszoltak. Sokan azok közül, akik ismerték a fogalmakat nem találkoztak még animátorral, nem vettek részt foglalkozásukon, vagy egyáltalán nem ismertek környezetükben olyan személyt, aki animátorként dolgozott. A 76 megkérdezettből 65-en nem ismernek animátort. 11 volt az igen válaszok száma (ezt azok választották, akik az előző kérdésre „igen”-nel válaszoltak.). A 11 „animátort ismerők" közül is csak néhányan írtak példát, amelyek a következők voltak: „ismerős”, „Szathmári Márton”, „,barátnőm”, „Siófokon a strandröplabdát rendezték”, „Füzesgyarmaton találkoztam velük".

„Szívesen elhelyezkednél-e ilyen munkakörben?" (animátorként) kérdés volt a következő ebben a kérdésblokkban. A válaszok arányai a következőképpen alakultak (1.ábra).

A válaszadók közül 5 főt nem érdekel ez a munka. Négyen csak luxushajón dolgoznának. Tizenöten akkor választanák ezt a munkát, ha nem lenne más lehetőség és tizenöten azért helyezkednének el animátorként, mert ehhez

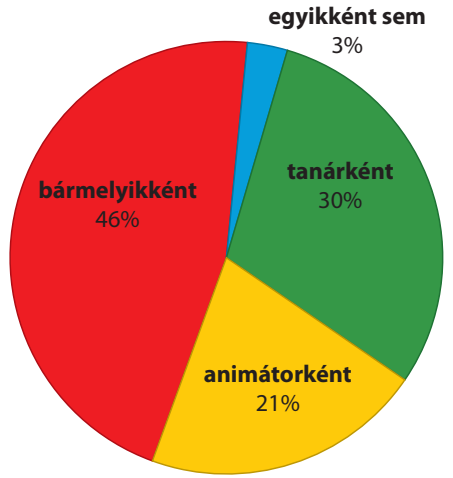

2. ábra • A tanári és animátori munkakör népszerüségének alakulása

2. figure • Popularity of PE teacher and animator job

Ez a kérdés azért fontos, mert a 46\% „bármelyikként elhelyezkednénk” eredmény azt tükrözi, hogy az animációnak van létjogosultsága, tanítani kellene turisztikai és animáció tárgyakat a testnevelés szakon. Így a tanári pálya mellett a szabadidő gazdaság vagy turizmus területén való elhelyezkedési esélyek növekednének.

A föiskola, oktatás és az animáció esetleges kapcsolatának felmérése:

Két eldöntendő kérdést tettem fel a hallgatótársaimnak ebben a csoportban.

Mindkét kérdésemre az „igen” választ vártam túlnyomó többségben. A válaszok a következőképpen alakultak:

Tanulna- e többet, ha ez növelné az elhelyezkedési lehetőségeit? A válaszadók 89\%-a (67 fö) hajlandó lenne többet tanulni, amennyiben javíthatna a munkaerő-piaci megítélésén, elhe- 
lyezkedési esélyein, míg a válaszadók csupán 11\%-a (9 fö), nem mutat erre hajlandóságot.

Amennyiben a föiskola szervezésében lenne egy olyan nap, ahol megismerhetnéd közelebbről az animátor munkáját, szívesen részt vennél rajta? A válaszadók 96\%-a (72 fó) szívesen bővítené ismereteit az animációról, az animátori munkáról és szívesen tájékozódna az elhelyezkedési esélyeiről.

\section{KövetKeZtetés}

Hazánk Európai Uniós csatlakozása, a tagállamokban zajló Bologna folyamat új kihívások elé állította a felsőoktatást, 2006 őszétől induló Bsc alapképzés elnevezése „Testnevelö, edző” lett, mely természetesen nem csak elnevezésbeli, de komoly strukturális és tartalmi változásokat eredményezett a tantervi anyagban és jól definiált oktatási módszereket kíván. Az alapszak elvégzése után lehet testnevelő tanár mesterképzésre jelentkezni, amely elvégzésével jogosultságot kap, hogy taníthasson.

Éppen ezért a leendő szakemberek képzésében egy új típusú testnevelés-szemléletet (Kristonné, 2006) követel, mely így a magvetőtőke szerepét kívánja erősíteni.

- A sportszakember képzés alapképzési szak tantervében, a választható tantárgyakon keresztül szerepeltetni kell, minél többféle sportágat, hogy minél többféle mozgásanyaggal ismerkedjenek meg a hallgatók.

- Felkészítésükben a turizmus, egészségturizmus, rekreáció ismeretanyagának elsajátításában a kompetenciák kialakítása kerüljön előtérbe. A megszerzett elméleti ismeretanyagot tudják a gyakorlatban alkalmazni (egy meghatározott célcsoport igényeinek összeállított szabadidős programcsomag megtervezése, ezek lebonyolítása team-munkában).

- A mesterképzésben az oktatás módszertani ismereteket, a tábor- és túrszervezés módszertani kérdéseinek gyakorlat-centrikus elsajátítása kell, hogy szerepeljen.

- Nyelvi kompetenciák (magyar és legalább egy idegen nyelven) fejlesztése, a kommunikációs technikákra, szituációs gyakorlatokra fókuszálva.

- A protokoll, etikett alapvető szabályainak elsajátítása nem csak a turizmus területén de a mindennapi vagy az üzleti élet területén is nélkülözhetetlen.
Megállapítható, hogy a testnevelö tanárok megjelenésével a továbbiakban is számolhatunk az egészségturizmus wellness területén. Éppen ezért fontosnak ítéljük, hogy a testnevelők képzésébe épüljön be a turizmust feldolgozó ismeretanyag. A közalkalmazottaknak hét évente továbbképzés területén kredit pontokat kell gyüjteni kötelező jelleggel, így a továbbképzések kurzusaiba is célszerű lenne beépíteni az egészségturizmussal kapcsolatos ismereteket.

- A turisztikai trendekre vonatkozóan elmondhatjuk, hogy a turizmus és ezen belül a wellness turizmus kereslete dinamikus fejlödést mutat.

- A wellness kínálati elemei között hangsúlyozottan jelentkeznek a szabadidős és sportprogramok, melyeknek a sikeres, színvonalas lebonyolításában, a programok animálásában jelentős szerep hárul a testnevelökre.

- A testnevelő tanárok felkészítésében markánsabban szerepeltetni kell a turisztikai és animációs ismereteket, és a programszervezéshez, vendéglátáshoz szükséges kompetenciák kialakítását.

\section{IRODALOMJEGYZÉK}

1. Istvánfy Csaba (1999): összefogás az ifjúság egészségéért, edzettségéért. In.: Öszszefogás az Ifjúság egészségéért, edzettségéért, A Magyar testnevelő Tanárok Országos Egyesületének Országos Szakmai Konferenciájának kiadványkötete 1990. 03. 10. (szerk. Istvánfi Cs.)15-34.p.

2. Révai Nagy Lexikona (1991)VI. kötet. Szépirodalmi és Babits Könyvkiadó, Bp. 163.p.

3. Buda Béla (1998):Elmélet és alkalmazás a mentálhigiénében. Bp. TÁMASZ, 25.p.

4. Der RDA Marktforschungsbericht 2009, Reyseanalyse 2009

5. Der RDA Marktforschungsbericht 2009. 13.p.

6. Kenneth H Cooper (1990) A tökéletes közérzet programja. Sport, Bp.19-26.p.

7. Kristonné dr. Bakos Magdolna (2006): Új szemléletű iskolai testnevelés az ezredfordulón. In: Acta Academiae Pedagogicae AgriensisAz Eszterházy Károly Főiskola tudományos közleményei. XXXIII. Kötet. Eger. 153-158.p.

8. Maslow, A.H (1968): Toward a psychology of being. Van Nostrand Reinhold Company Incorporation, N.Y.

9. http://www.spahungary.hu/lap. php?id=17
10. Dr. Wolfgang Nahrstedt (2000): Der Wellnessurlaub, Marktgerechte Angebote Gesundheitstourismus europäischer Kur- und Urlaubsorte; Heilbad und Kurort, 2000. 08. 171-173.p.

11. Müller Anetta-Könyves Erika (2006): A testnevelő tanárok kapcsolódási pontjai az egészségturizmushoz. In: Acta Academiae Pedagogicae Agriensis- Az Eszterházy Károly Főiskola tudományos közleményei. XXXIII. Kötet. Eger. 119-132.p.

12. Ggedő Dolóresz-Rigler Endre (1998): Labdás gyakorlatok a mozgásterápiában. Present Bt., Kecskemét. 5-15.p.

13. Marketingterv 2004. Magyar Turizmus Rt. 2003. okt. 7. 1-119.p. (www.itthon.hu)

14. Révai Új Lexikona (1996) I. kötet. Babits Kiadó, Szekszárd. 497.p.

15. Révai Nagy Lexikona (1989). Az ismeretek Enciklopédiája. I. kötet. Szépirodalmi és Babits Könyvkiadó. 658.p.

16. Kristonné dr. Bakos Magdolna (2006): Új szemléletű iskolai testnevelés az ezredfordulón. In: Acta Academiae Pedagogicae AgriensisAz Eszterházy Károly Főiskola tudományos közleményei. XXXIII. Kötet. Eger. 153-158.p.

17. KSH 2009, www.itthon.hu

18. Kerényi Erika-Dr. Müller AnettaSzabó Róbert-Dr. Mosonyi Attila(2009): Analysis of Agárd, Komárom and Pápa's Thermal and Experiences Bath, according the guest's satisfaction. Egészségügyi marketing éstelekommunikáció címủ konferencia kiadványkötete (CD). ISBN:978-963-06-8473-6., 11.o.

19. Dr. Müller Anetta-Szabó RóbertKerényi Erika-Dr. Mosonyi Attila PhD. (2009): Fürdőkutatás a Közép-dunántúli régióban. In. Acta Academiae Pedagogicae Agriensis. XXXVI. Sectio Sport. Sport, életmód, egészség. Az Eszterházy Károly Főiskola tudományos közleményei. Szerkesztő: Honfi László. 65-77.p.

20. Mosonyi Attila-Könyves Erika-Kerényi Erika-Müller Anetta (2010): Miskolctapolca egészségturizmusa egy vizsgálat tükrében. International Conference of Tourism, Recreation and Sports Management. 27-28 th May 2010.kiadványkötete (CD) 8.o.

21. Müller Anetta-Kórik Valéria (2009): Az Észak-alföldi fürdők szerepe a turizmusban és a rekreációban. In. Economica 2009/2. szám.5872.p. ISSN:1585-6216 